\title{
OUR LADY OF IMPOSSIBILITY
}

\section{Gendered Standards in Islam and Christianity}

IN BOTH CHRISTIANITY AND ISLAM, MARY REPRESENTS PERHAPS THE HIGHEST SOCIETAL IDEAL OF WHAT A WOMAN CAN STRIVE TO BE. THIS PAPER COMPARES THE CONSTRUCTION OF THAT STANDARD IN THESE TWO RELIGIOUS TRADITIONS AND ITS IMPLICATIONS FOR WOMEN. ADDITIONALLY, MARY IS COMPARED TO OTHER IMPORTANT RELIGIOUS FIGURES, SUCH AS THE PROPHET MUHAMMAD AND FÁTIMA. GIVEN HOW MUCH ATTENTION MARY'S BODY RECEIVES IN CHRISTIANITY AND ISLAM, A CRUCIAL PART OF THE DISCUSSION FOCUSES ON BODIES, SEXUALITY, AND PURITY AS A PHYSICAL AS WELL AS SPIRITUAL CONCEPT. THREE CONCLUSIONS CAN BE DRAWN FROM THIS INVESTIGATION: FIRSTLY, THE STANDARD PRESENTED BY THE VIRGIN MARY IS GENDERED IN THE WAY THAT IT IS APPLIED PREDOMINANTLY TO WOMEN. SECONDLY, IT IS INHERENTLY UNATTAINABLE. FINALLY, UNDER SUCH A STANDARD, WOMEN ARE SET UP TO FAIL AT PERFORMING AND ACHIEVING THIS IDEAL IN THEIR RESPECTIVE FAITHS. THE APPROPRIATION OF MARY'S LIFE AND LEGACY IS DISCUSSED AS A PATRIARCHAL FIXTURE WHICH SERVES TO EXPLAIN ONE CAUSE OF BOTH PAST AND CURRENT GENDER INEQUALITY. 
9 Mary as an individual, idea, and influence is neither solely feminine nor solely Christian. Amy Remesnyder describes her as "mother, virgin, bride, apocalyptic messenger, inimitable paragon, model of femininity, punisher of sin, fountain of consolation, queen of heaven, and more...[a] shape-shifter who turns such diverse and even divergent faces toward her devotees." She is not just a woman, but a mystical figure across religious traditions; nor is she simply a role model for people of faith, but an unattainable yet mandated standard. The significance of her role is highlighted in Christian as well as Islamic traditions. This article will discuss the status of Mary and other models of faith as unattainable, gendered standards and examine its implications within both Christianity and Islam.

First, it is important to outline the respective Christian and Islamic accounts of Mary. The two depictions are in fact quite similar. In both traditions, Mary is a young, pious virgin who conceives and gives birth to Jesus. The differences are in the contexts and details of this narrative: In the Christian tradition, Mary's story begins with her own immaculate conception and continues to the Annunciation of her role as the mother of God by the angel Gabriel. She gives birth to Jesus, the Messiah and Emmanuel, with the support of her husband, Joseph. She is finally assumed into heaven upon her death. ${ }^{2}$ In Islamic tradition, on the other hand, Mary is safe from sin due to a prayer of her mother's and lives a relatively isolated life of devotion to God. Joseph is her "zealous partner in prayer" rather than her husband. ${ }^{3}$ The angel Gabriel informs her that she will

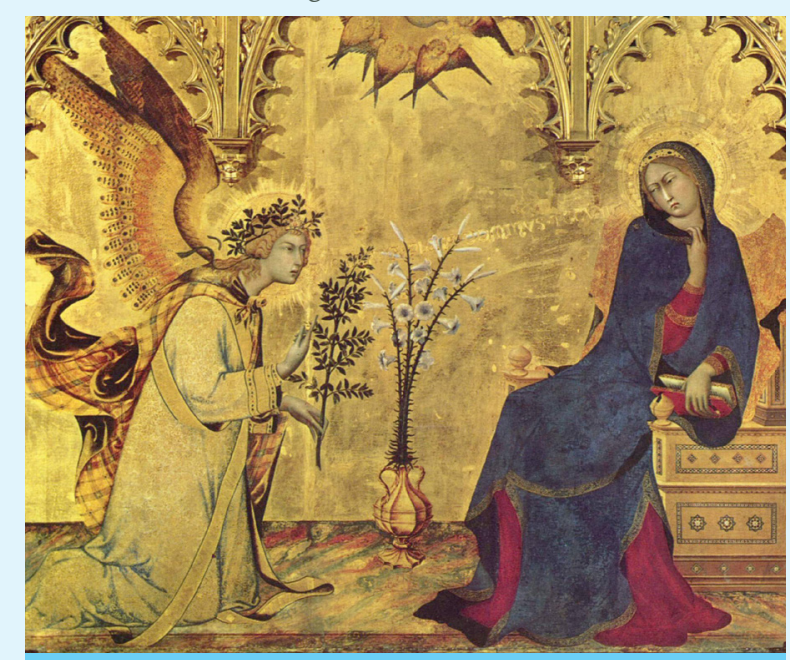

THE VISIT OF THE ANGEL GABRIEL TO THE VIRGIN MARY (COURTESY OF WIKIMEDIA COMMONS) conceive and give birth to a son who is a prophet. Mary then gives birth alone and is supported by a voice which could be God's, and her son Isa fulfills his role as prophet. Islamic tradition also maintains that Mary is in heaven. ${ }^{4}$ Maura Hearden presents a side by side analysis of these two accounts and argues that they each encourage different elements of the practice of faith. To Hearden, the Christian account of Mary emphasizes trinitarianism and community in the form of the Church. ${ }^{5}$ In contrast, the Islamic account highlights "God's sovereign power and... one's individual responsibility to submit" as well as having an "emphasis on individual activity" in general. ${ }^{6}$

Despite these differences, Mary is regarded as a standard of faith in both traditions. In a I989 article that has been referenced in several other sources, Smith and Haddad identify Mary as a major female figure in the Quran. ${ }^{7}$ They describe how she was placed on the same level as Khadijah, Fátima, and Asiya, the three Muslim women to receive the highest level of honor. ${ }^{8}$ Placing Mary on the same level as them endorses her as a Muslim ideal, even though she has traditionally been known as a Christian one. Arguably, Islamic tradition considers her so special that she receives something of a "free pass" to exceptional status and regard, a privilege not conferred on the other women mentioned above. Smith and Haddad confirm this by pointing out that in certain interpretations, Mary and another woman are held above even the other two of the four. ${ }^{9}$

The two key elements of Mary in both traditions are her purity and obedience. Hearden outlines that in Islam:

The proper response to one's Lord and Master is complete, un questioning submission to God's divine will. This is the primary focus of Mary's story -- total submission to God's power.. The qu'ranic Mary is expected to believe and submit [at the Annunciation] without any explanation except that it is her Master's will...In the Qur'an, God does not ask for Mary's assent but assumes it, because she is bound to give it. ${ }^{\text {Io }}$

Hearden distinguishes between the obedience of Mary in Islamic and Christian traditions, clarifying that Mary is portrayed as willfully choosing obedience in Christian texts. ${ }^{\text {II }}$ Still, Mary's obedience is a cornerstone of how her role is understood in both traditions, and is therefore crucial to the value placed on her. In terms of purity, which will be returned to later in this analysis, Hearden states simply that "Mary's virginity of body, heart, and mind is a prerequisite for the birth of the Christ." ${ }^{2}$ 


\section{"Mary is lauded as being at her best, and modeling the best of what it is to be a woman, in being devoid of agency and sexual functioning."}

An interesting dimension to consider is the links made between Fátima and Mary. Muhammad's daughter, Fátima is considered to be Mary's Islamic counterpart by a number of sources, and their shared status approaches conflation into one superwoman. As Smith and Haddad put it, "in some cases Mary and Fátima seem almost to be abstracted into one person." ${ }_{13,14}$ Thurlkill explains of Fátima:

[S]he never menstruates, and she bears her sons without blood loss or other contamination. Instead of exemplifying corporal integrity, Fátima's status as virgin connotes paradisiacal perfection free from impurities. She is, by her essence, sacred..$^{15}$

The melding of this standard set by Fátima with that of Mary blurs the boundaries between Christian and Islamic expectations for women. Mary and Fátima together serve as a quantitatively and ideologically massive standard which, by nature, crosses religious lines. This effect may be considered particularly strong for Muslim women the similarities between two of the most revered women in Islamic tradition naturally result in mutual reinforcement of the standards set by each one.

This and other forms of attention given to Mary establish her as a figure to be admired in Islam, but the religious endorsement of her person solidifies her standing as a model of how one should perform faith. In "Mary of the Koran," Geoges refers to texts describing Mary as "chosen" by Allah and says that as she was "[c]hosen and predisposed by God...Mary had to shine together with [Christ] as a prodigious sign [ayat] for all creation, and as a resplendent model [mathal] for all believers." ${ }^{16}$ Smith and Haddad also make a point of mentioning that Mary is exceptional in receiving by-name recognition in the Quran, a point corroborated by Geoges. ${ }^{17}$ According to Geoges, "[i]t seems as though, in Mary's presence, all other women were something amorphous, evanescent, inconsistent; as though Mohammad wanted deliberately to cast on them all a shadow, and then place in the limelight the only woman truly worthy of this name - Mary." 18 This further establishes Mary as the embodiment of a specifically religious standard in Islam, as she is in Christianity.
Despite the fact that nearly all of this discussion operates on the basis of Mary's status as a woman and in comparison to other women, it is necessary to determine the extent to which the standard she sets is gendered. In a 2013 article, Axel Takacs, a Catholic man, sets forth the extended argument that Mary and Muhammad are simply analogs of each other. While not the aim of Takacs's writing, his argument effectively erases any role or impact of gender on the significance of these figures in Christianity and Islam. However, I would argue that the religious standards set by both individuals are highly gendered, and this feature is of great importance to understanding how they affect believers and the practice of faith.

Takacs connects Muhammad and Mary on the basis that both serve as the "word-bearers" for their faiths and peoples. ${ }^{19}$ He refers to a scholar named Schimmel who asserts that their capacities for that act of bearing were made possible by their purity -- Mary in her virginity and Muhammad in his illiteracy. ${ }^{20}$ This equation of virginity to illiteracy is repeatedly made and inherently problematic in its denial of the gendered elements of the situation:

In each Word-bearer, the receiving of the Word of God was an act of pure and sublime grace of God; Muhammad and Mary played no part in meriting such a mission. For Muhammad, his intellectual activity was not involved in reciting the Qur'an, while, for Mary, her sexual activity was not involved in the bearing of Jesus. ${ }^{21}$

The fact of the matter is that virginity cannot be considered the equivalent of illiteracy. Takacs' comparison of Mary and Muhammad under this supposition is invalid. At the most basic level, virginity is a morally charged concept while illiteracy is not. In particular, Takacs' statement that Mary and Muhammad "played no part in meriting such a mission" is negated by the gendered differences between the two individuals. According to Takacs, illiteracy, as a state unrelated to morality, can be treated as the passive absence of a quality which Takacs posits it as being. However, Mary's virginity is not passive, but rather, as Hearden indicates, exactly that which "merits" her role as Jesus' 
9 mother. ${ }^{22}$ Takacs' implication here is that sexual activity or literacy would somehow have 'earned' the roles of wordbearer for Mary and Muhammad. While this could be true of Muhammad becoming literate, Mary would not have earned anything but societal disapproval if she had become sexually active. The converses of each state also reveals deep differences between the two: a woman who is not a virgin is likely to be socially stigmatized and punished, whereas a man who is literate is likely to be among the most highly rewarded members of society. Muhammad's illiteracy was likely nothing more than circumstance and an unfortunate lack of education. While unfair, he was not morally or societally mandated to remain illiterate in the same way that women, of Mary's time and beyond, have been compelled to remain virgins before marriage. Furthermore, Mary was likely illiterate herself, while this symbol of "purity" which made Muhammad a "wordbearer" was insufficient in her situation.

This dichotomy reveals the emphasis on purity which demonstrates the truly gendered nature of Mary as a religious standard. Mary, as well as Fátima and other women, has been reduced solely to her purity. Thurlkill describes Mary and Fátima both as "vessels" and "undefiled containers." ${ }^{23}$ Within this paradigm, the significance of Mary and women like her is emptied of all but their womanhood. This holds true no matter how one considers purity, as there is a consensus in the literature that both Christian and Islamic texts are referring to Mary's physical and spiritual purity. ${ }^{24}$ Smith and Haddad reference a scholar named Al-Alusi who held that "God gave Mary the privilege of being pure from all uncleanness in the literal and figurative senses, both of the heart and of the body." ${ }^{25}$ Furthermore, menstruation was understood to be decidedly impure - "defiling and in itself destructive of a state of purity." ${ }^{26}$ The intimate tying of a woman's purity to the absence of sexual activity or menstruation affirms that the only relevant part of a woman is her womanhood itself. In this, the standard set by Mary is undeniably applied more to women than to men.

This standard is, by definition, gendered and impossible to attain. Though Takacs argues that it is possible for all people to "imitate Mary's virginity...by emptying themselves of their pretensions of pride and self-delusions," most women will inevitably menstruate. ${ }^{27}$ Even if the physical purity were irrelevant, the spiritual purity Takacs and others speak of still amounts to a complete emptying. Mary is lauded as being at her best, and modeling the best of what it is to be a woman, in being devoid of agency and sexual functioning. A lack of inner substance is ultimately the characteristic to which Islamic and Christian traditions attribute Mary's great worth. Additionally, the physical purity of Mary can never be anything but relevant -- it is treated as necessary proof of any other sort of purity she may possess, and her story would not exist in the same way were she not considered physically pure.

The gendered nature of Mary's example of purity is further supported by comparison to Muhammad. Takacs describes Muhammad's person as "son, orphan, merchant, arbiter, warrior, husband, father, and statesperson, and so he was able to incorporate "other-worldly" and spiritual attitudes into "this-worldly" actions...Muhammad himself is seen as purifying the sexual act." ${ }^{28}$

This is important in several ways. As a man, Muhammad's actions have the power to set new standards about external actions, extrapolating value from recognition of Muhammad's intrinsic goodness. This is the exact opposite of Mary, whose worth and goodness are dictated by the same external factors over which Muhammad has power. While Muhammad's actions can define sex as pure, Mary has no choice but to be defined as pure by sex. This is evidence of a power structure in which men have power over social values, which in turn exert power over women. For all the respect she receives, Mary's status is at the mercy of societal values.

The unattainability of Mary in combination with the gendered and mandated nature of the religious standards built up around her is ultimately harmful to women. In her review of works on Mary, Remesnyder concisely states that

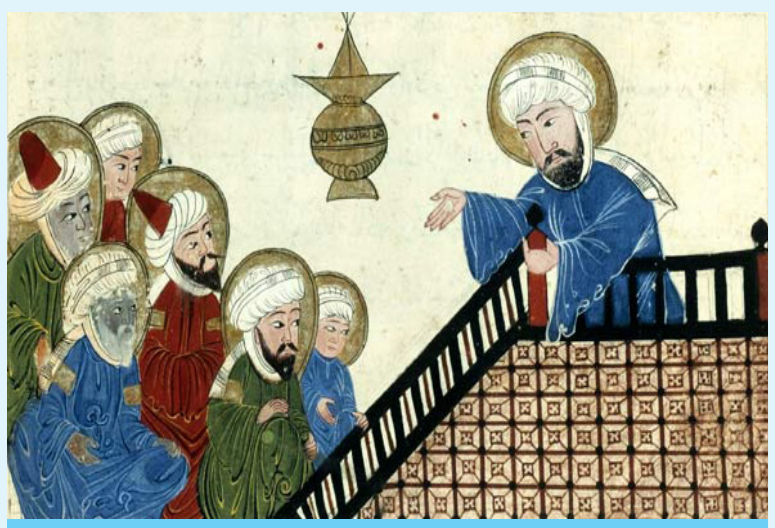

MUHAMMAD PREACHING TO HIS FOLLOWERS (COURTESY OF WIKIMEDIA COMMONS) 
“No woman could ever achieve Mary and Fátima's transcendence of the pollution inherent to the female body." ${ }^{29}$ Smith and Haddad concur, highlighting the impossibility of being like Mary or Fátima, and that menstruation results in women being "define[d]...out of the possibility of leadership in a house of worship." ${ }^{\circ}$ Smith and Haddad elaborate on what this unattainability results in:

Women can...be admonished through reference to Mary's virtue in two limited but very significant ways. While ultimately not as pure as she was, they are expected to aspire to this ideal to the extent to which they reserve themselves for their husbands and come to them untouched and undefiled. And as Mary was the embodiment of perfect obedience, Muslim women are enjoined to be obedient not only directly to God, but indirectly through the obedience that they show to the men to whom they are unquestionably responsible..$^{31}$

Mary's significance as a woman is framed entirely within a patriarchal view that rejects the truth of cisgender femaleness. She is full of contradictions: the ultimate virgin and the ultimate mother; menstrual evidence of reproductive ability, yet having the ability to bear a child practically on command. As stated by the authors cited previously, and as common sense would indicate, no woman in real life can fulfill all of these. Thus, it is highly unlikely that the popular and religious understandings of Mary today could accurately represent her as an individual. The standards set by retellings of who she was are significantly lacking in recognition of who she was apart from the obedient virgin. This not only denies the realities of modern women's experiences, but also subverts the life and actions of an iconic woman into the same sort of patriarchal standard under which she would have been confined. It means, above all, that female believers aspiring to be good women of faith will inevitably fail. The inclusion of purity in this standard is demeaning to all women as it is to Mary, who is considered important to a large extent for nothing more than the state of her body. The conclusion which follows from this is that a woman is, for the most part, just a body.

If the models of ideal faith are gendered, and those specifically gendered models are unattainable, then men and women have very different levels of access to successful and socially approved performances of faith. The impossibility of such standards means that female believers across multiple faiths would always fall short of religious ideals. This perpetual failure results directly from the gendering of religious standards, and women experience it in ways that male believers do not. The standards of religious behavior for women set by Mary's example are patriarchal at their roots. Given the acceptance of menstruation as "defiling," the conflation of Mary's virginity with her worth, and the reduction of her identity and value to being the obedient owner of a uterus, it becomes clear that the ways in which we affirm Mary matters are framed within the rules of what matters most for men. It cannot be ignored that this sets women up to fail - at faith, at goodness, and at ever gaining equality within a still-patriarchal world.

\section{ENDNOTES}

I. Remesnyder, A. "Meeting the Challenges of Mary." Journal of Women's History 25 (20I3): I95-206. doi: IO.I353/jowh.20I3.000I, I95.

2. Hearden, M. "Ambassador for the Word: Mary as a Bridge for Dialogue between Catholicism and Islam." Journal of Ecumenical Studies 4I.I (2004): I8-38. Print.,. 2I-25.

3. Ibid., 22.

4. Ibid., 2I-25.

5. Ibid., 26,28 .

6. Ibid.,. 26

7. Smith, J., and Y. Haddad. "The Virgin Mary in Islamic Tradition and Commentary." The Muslim World 79 (I989): I6I-

87. Print.,. I62.

8. Ibid., I79.

9. Ibid., I79.

Io. Hearden, M. "Ambassador for the Word: Mary as a Bridge for Dialogue between Catholicism and Islam." Journal of Ecumenical Studies 4I.I (2004): I8-38. Print., 34

II. Ibid., 35-36

I2. Ibid., 36 .

I3. Thurlkill, M. Chosen among Women: Mary and Fatima in Medieval Christianity and Shi'Ite Islam. Notre Dame, IN: University of Notre Dame, 2007. Print. (p. 60-6I);Smith, J., and Y. Haddad. "The Virgin Mary in Islamic Tradition and Commentary." The Muslim World 79 (I989): I6I-87. Print.,. I79I8I.

I4. Smith, J., and Y. Haddad. "The Virgin Mary in Islamic Tradition and Commentary." The Muslim World 79 (I989): I6I87. Print., p. I79.

I5. Thurlkill, M. Chosen among Women: Mary and Fatima in Medieval Christianity and Shi'Ite Islam. Notre Dame, IN: University of Notre Dame, 2007. Print., 6o.

I6. Geoges, N. Mary of the Koran: A Meeting Point between Christianity and Islam. Tran. L. Fares. Ed. L. Fares. New York, NY.: Philosophical Library, Inc., I984. Print., I25,I27: Ibid., I20. I7. Smith, J., and Y. Haddad. "The Virgin Mary in Islamic Tradition and Commentary." The Muslim World 79 (I989): I6I87. Print., p. I62; Geoges, N. Mary of the Koran: A Meeting Point between Christianity and Islam. Tran. L. Fares. Ed. L. Fares. New York, NY.: Philosophical Library, Inc., I984. Print., II5-II8. I8. Geoges, N. Mary of the Koran: A Meeting Point between Christianity and Islam. Tran. L. Fares. Ed. L. Fares. New York, 
9 NY.: Philosophical Library, Inc., I984. Print. II6.

I9. Takacs, A. "Mary and Muhammad: Bearers of the Word--their Roles in Divine Revelation." Journal of Ecumenical Studies 48.2

(20I3): 220-43. Print., 225.

20. Ibid., 228,229.

2I. Ibid.,. 228-229.

22. Hearden, M. "Ambassador for the Word: Mary as a Bridge for Dialogue between Catholicism and Islam." Journal of Ecumenical Studies 4I.I (2004): I8-38. Print., 36.

23. Thurlkill, M. Chosen among Women: Mary and Fatima

in Medieval Christianity and Shi'Ite Islam. Notre Dame, IN:

University of Notre Dame, 2007. Print.,. 5I, 64.

24. Smith, J., and Y. Haddad. "The Virgin Mary in Islamic

Tradition and Commentary." The Muslim World 79 (I989): I6I-

87. Print., I73.

25. Ibid., I74.

26. Ibid., I72-I73.

27. Takacs, A. "Mary and Muhammad: Bearers of the Word--their

Roles in Divine Revelation." Journal of Ecumenical Studies 48.2

(2013): 220-43. Print, 229.

28. Ibid.,. 224.

29. Remesnyder, A. "Meeting the Challenges of Mary." Journal of Women's History 25 (2013): I95-206. Print. DOI: IO.I353/ jowh.20I3.000I, 200.

30. Smith, J., and Y. Haddad. "The Virgin Mary in Islamic

Tradition and Commentary." The Muslim World 79 (I989): I6I-

87. Print.,. I87.

3I. Ibid.

\section{REFERENCES}

Geoges, N. Mary of the Koran: A Meeting Point between Christianity and Islam. Tran. L. Fares. Ed. L. Fares. New York, NY.: Philosophical Library, Inc., I984. Print.

Hearden, M. “Ambassador for the Word: Mary as a Bridge for Dialogue between Catholicism and Islam." Journal of Ecumenical Studies 4I.I (2004): I8-38. Print.

Remesnyder, A. "Meeting the Challenges of Mary." Journal of Women's History 25 (2013): I95-206. Print. DOI: IO.I353/ jowh.2013.000I

Smith, J., and Y. Haddad. "The Virgin Mary in Islamic Tradition and Commentary." The Muslim World 79 (1989): I6I-87. Print.

Takacs, A. "Mary and Muhammad: Bearers of the Word-their Roles in Divine Revelation." Journal of Ecumenical Studies 48.2 (2013): 220-43. Print.

Thurlkill, M. Chosen among Women: Mary and Fatima in Medieval Christianity and Shi'Ite Islam. Notre Dame, IN: University of Notre Dame, 2007. Print. 